\title{
Vascular Endothelial Growth Factor Production and Regulation in Rodent and Human Pituitary Tumor Cells in vitro
}

\author{
Penny Lohrer ${ }^{a}$ Jutta Gloddek ${ }^{a}$ Ursula Hopfner ${ }^{a}$ Marco Losab \\ Eberhard Uhlc Uberto Pagotto ${ }^{a}$ Günter K. Stalla ${ }^{a}$ Ulrich Renner ${ }^{a}$ \\ a Max Planck Institute of Psychiatry, Department of Endocrinology, Munich, and ${ }^{\mathrm{C} D e p a r t m e n t}$ of Neurosurgery,

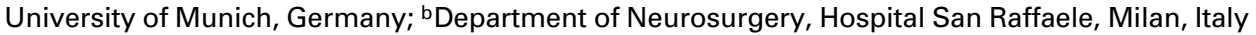

\begin{abstract}
Key Words
Vascular endothelial growth factor - Pituitary tumors . Angiogenesis - Pituitary adenylate cyclase-activating polypeptide $\cdot$ Interleukins · Growth factors .

Somatostatin - Pituitary cell lines - Adrenal steroids · Human - AtT20 cell line - GH3 cell line - aT3 cell line
\end{abstract}

\begin{abstract}
Angiogenesis, the formation of a new blood supply, is an essential step in tumorigenesis. Although vascular endothelial growth factor (VEGF) is known to be a very potent angiogenic factor in most solid tumors, little is known about its production and regulation in pituitary adenomas. We have investigated basal and stimulated VEGF production by rodent pituitary tumor cells (mouse corticotrope AtT20, rat lactosomatotrope GH3, mouse gonadotrope $\alpha \mathrm{T} 3-1$ and mouse folliculostellate TtT/GF cells), and by hormone-inactive (27), corticotrope (9), lactotrope (3) and somatotrope (21) human pituitary adenoma cell cultures. All 4 pituitary cell lines secreted VEGF, which in the case of AtT20, GH3 and TtT/GF cells was inhibited by approximately $50 \%$ by dexamethasone. TtT/GF cells were the most responsive to the different stimuli used since basal values were augmented by pituitary adenylate cyclase activating polypeptide-38 (PACAP-38), interleukin-6 (IL-6), trans-
\end{abstract}

\section{KARGER}

Fax +41613061234

E-Mail karger@karger.ch

www. karger.com

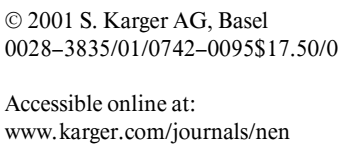

forming growth factor- $\alpha$ (TGF- $\alpha$ ), IGF-I and the somatostatin analogue ocreotide. However, in GH3, AtT20 and aT3-1 cells, basal VEGF levels where not enhanced with any of the stimuli tested. The majority of the human adenomas tested (92\%) basally secreted measurable VEGF which was inhibited by dexamethasone in most cases (84\%). VEGF levels were increased in hormone inactive adenomas, somatotrope tumors and prolactinomas by TGF- $\alpha$, PACAP-38, and $17 \beta$-estradiol, respectively. In conclusion, pituitary tumor cells are capable of producing VEGF which may be involved in tumoral angiogenesis. Our results concerning the suppression of VEGF by dexamethasone suggest that glucocorticoids may have anti-angiogenic properties and therefore therapeutic relevance for the treatment of pituitary adenomas.

Copyright @ 2001 S. Karger AG, Basel

\section{Introduction}

As for any solid tumor, neovascularization of pituitary adenomas is required in order to supply the tumor cells with nutrients and oxygen. In addition, the generation of a direct arterial blood supply during neovascularization has fundamental functional consequences for endocrine adenoma cells, since it uncouples the pituitary tumor cells 
from the portal blood vessel system and thus from hypothalamic control [1-3]. Anti-angiogenic treatment strategies for pituitary adenomas might be helpful to reduce this direct arterial blood supply, and, in this way, restore in particular the inhibitory influences of the hypothalamus on the endocrine tumor cells. VEGF is considered to be the most important angiogenic factor involved in the neovascularisation of solid tumors. To date, anti-angiogenic strategies in the treatment of tumors mainly focus on the suppression of VEGF production, or the down-regulation of its receptors [4-6].

Vascular endothelial growth factor (VEGF) is a homodimeric glycosylated protein of $46-48 \mathrm{kD}(24 \mathrm{kD}$ subunits) [6] produced by numerous cell types including fibroblasts [7, 8], mesangial cells [9] and keratinocytes [10]. As a result of alternative splicing VEGF occurs in several isoforms which in humans are 121, 145, 165, 189 and 206 amino acids long [11-13]. VEGF has been demonstrated to have many biological functions such as enhancing vascular permeability [5] and increasing metastases formation [14]. However, its major function appears to be that of angiogenesis in tumorigenesis [15], wound healing [16], embryo organ development $[16,17]$ and during reproduction functions in the adult [18].

VEGF has two structurally related tyrosine kinase receptors, flt-1 and flk-1 (KDR), which appear to have quite different functions. Flk-1 has been demonstrated to be involved in actin re-organization [19], chemotaxis [19], blood island formation and vasculogenesis in mouse embryos [20], whereas flt-1 has been reported to be involved in nitric oxide production [21] and the organisation of the embryonic vasculature [22].

VEGF has been demonstrated to be expressed in the normal pituitary only in folliculostellate (FS) cells [23, 24]. In a small number of pituitary adenomas studied, VEGF mRNA and protein expression could also be detected by PCR [25] and by immunohistochemistry [26], but at present it is not clear by which cell types VEGF is produced inside the tumors. VEGF has also been found in corticotrope AtT20 [27] and lactosomatotrope GH3 cells [28]. In the latter, VEGF production has been demonstrated to be stimulated by estrogen [28]. VEGF expression is enhanced in Fischer 344 rats during the development of estrogen-induced prolactinomas $[29,30]$. In folliculostellate TtT/GF pituitary tumor cells, IL-6 and PACAP-27/38 stimulated VEGF release, whereas it was suppressed by dexamethasone [31]. VEGF secretion by rat pituitary cell cultures was regulated by IL-6, PACAP and dexamethasone in an identical manner [31], suggesting that the regulation of VEGF production in normal and tumorous FS cells is very similar. However, apart from these few studies, little is known concerning the regulation of VEGF within the normal pituitary and especially in pituitary tumors. Therefore, we have determined basal VEGF levels in 4 different rodent pituitary tumor cell lines and in different types of pituitary adenomas and have studied VEGF secretion in response to an array of different substances that are known or thought to affect pituitary adenoma development.

\section{Material and Methods}

\section{Patients}

The present study was approved by the ethics committee of the Max Planck Institute of Psychiatry (Munich, Germany) and was undertaken after informed consent was received from each patient. Pituitary adenomas were diagnosed by plasma pituitary hormone testing and magnetic resonance imaging as previously described [3234]. The characteristics of the tumors, divided according to their clinical symptoms, are shown in tables 1 and 2. No hormonal excess was found in any of the patients with clinically inactive adenomas although routine immunohistochemical evaluation showed immunoreactivity for $\mathrm{LH}, \mathrm{FSH}$ or $\alpha$-subunit in cellular subsets in most of these adenoma tissues (not shown). Elevated GH (range 19-97 $\mu \mathrm{g} / \mathrm{l}$ ) and IGF-I (range $844-2,737 \mu \mathrm{g} / \mathrm{l}$ ) serum concentrations were found in the group of patients with acromegaly. In some of the corresponding tumor tissues, proportions of cells were also immunopositive for PRL. Patients with corticotrope adenomas presented classical symptoms of Cushing's disease due to elevated ACTH (range 16.4$79.1 \mathrm{nmol} / \mathrm{l}$ ) and cortisol (range 416-1,089 nmol/l) levels. Corticotrope adenoma tissue was found to be immunoreactive only for ACTH. Elevated PRL serum levels (range 120-3,700 $\mu \mathrm{g} / \mathrm{l}$ ) were found in patients with lactotrope tumors. Two of the 3 prolactinomas had to be operated on because they were nonresponsive to dopamine agonist treatment; in the third case surgery was performed due to compliance problems. Only PRL immunoreactivity was detected by immunohistochemistry in the corresponding adenoma tissues.

\section{Materials}

Cell culture materials and reagents were obtained from Gibco (Karlsruhe, Germany), Falcon (Heidelberg, Germany), Nunc (Wiesbaden, Germany), Seromed (Berlin, Germany), Flow (Merkenheim, Germany) and Sigma Chemicals (St. Louis, Mo., USA). Mouse IL-6 was obtained from Roche Molecular Biochemicals (Mannheim, Germany). PACAP-38, IGF-I, and TGF- $\alpha$ were obtained from Bachem (Bubendorf, Switzerland). Dexamethasone and 17ß-estradiol (E2) were obtained from Sigma Chemicals, ocreotide was kindly provided by Novartis (Basel, Switzerland). Bromocriptine was purchased from RBI (Natick, USA).

\section{Pituitary Cell Line Culture}

$\alpha \mathrm{T} 3-1, \mathrm{GH} 3, \mathrm{TtT} / \mathrm{GF}$ and AtT20 cells were plated into 48 wells. All the cells were grown in Dulbecco's modified Eagle's medium ( $\mathrm{pH}$ 7.3) supplemented with $10 \% \mathrm{FCS}, 2.2 \mathrm{~g} / 1 \mathrm{NaHCO}_{3}, 10 \mathrm{~m} M$ HEPES, $2 \mathrm{~m} M$ glutamine, $10^{5} \mathrm{U} / 1$ penicillin-streptomyocin, and $2.5 \mathrm{mg} / 1$ amphotericin; however, the TtT/GF and $\alpha \mathrm{T} 3-1$ cell medium was further supplemented with $30 \mathrm{p} M$ tri-iodothyronine, $5 \mathrm{mg} / \mathrm{l}$ transferrin, 
Table 1. Characteristics of clinically hormone-inactive pituitary adenomas (HI 1 to HI 27)

\begin{tabular}{|c|c|c|c|}
\hline Tumor & Sex/age & Size $^{\mathrm{a}} /$ invasive $^{\mathrm{b}}$ & VEGFc $^{c}$ \\
\hline HI 1 & $\mathrm{M} / 77$ & macro/yes & $13.56 \pm 1.15$ \\
\hline HI 2 & $\mathrm{M} / 75$ & macro/yes & $2.72 \pm 0.08$ \\
\hline HI 3 & $\mathrm{~F} / 63$ & macro/no & $2.00 \pm 0.08$ \\
\hline HI 4 & $\mathrm{M} / 74$ & macro/no & $0.95 \pm 0.06$ \\
\hline HI 5 & $\mathrm{~F} / 17$ & $\mathrm{macro} / \mathrm{no}$ & $1.59 \pm 0.04$ \\
\hline HI 6 & $\mathrm{M} / 54$ & macro/no & $0.24 \pm 0.03$ \\
\hline HI 7 & $\mathrm{~F} / 64$ & macro/yes & $0.07 \pm 0.01$ \\
\hline HI 8 & $\mathrm{~F} / 50$ & macro/yes & $0.14 \pm 0.01$ \\
\hline HI 9 & $\mathrm{M} / 82$ & macro/no & $0.40 \pm 0.03$ \\
\hline HI 10 & $\mathrm{M} / 82$ & macro/yes & $1.47 \pm 0.01$ \\
\hline HI 11 & $\mathrm{M} / 50$ & macro/yes & $7.85 \pm 0.40$ \\
\hline HI 12 & $\mathrm{M} / 35$ & macro/yes & $0.88 \pm 0.08$ \\
\hline HI 13 & $\mathrm{M} / 78$ & $\mathrm{macro} / \mathrm{no}$ & $0.53 \pm 0.01$ \\
\hline HI 14 & $\mathrm{M} / 52$ & macro/no & $0.07 \pm 0.01$ \\
\hline HI 15 & $\mathrm{M} / 76$ & macro/yes & $1.07 \pm 0.13$ \\
\hline HI 16 & $\mathrm{M} / 39$ & $\mathrm{macro} / \mathrm{no}$ & $0.09 \pm 0.01$ \\
\hline HI 17 & $\mathrm{~F} / 31$ & macro/no & $2.55 \pm 0.003$ \\
\hline HI 18 & $\mathrm{M} / 49$ & $\mathrm{macro} / \mathrm{no}$ & nd \\
\hline HI 19 & $\mathrm{~F} / 64$ & $\mathrm{macro} / \mathrm{no}$ & $0.23 \pm 0.02$ \\
\hline HI 20 & $\mathrm{M} / 59$ & macro/no & $1.44 \pm 0.14$ \\
\hline HI 21 & $\mathrm{M} / 59$ & $\mathrm{macro} / \mathrm{no}$ & $0.70 \pm 0.06$ \\
\hline HI 22 & $\mathrm{~F} / 72$ & $\mathrm{macro} / \mathrm{no}$ & $0.92 \pm 0.09$ \\
\hline HI 23 & $\mathrm{M} / 60$ & $\mathrm{macro} / \mathrm{no}$ & $1.73 \pm 0.20$ \\
\hline HI 24 & $\mathrm{M} / 74$ & $\mathrm{macro} / \mathrm{no}$ & $2.54 \pm 0.09$ \\
\hline HI 25 & $\mathrm{M} / 41$ & $\mathrm{macro} / \mathrm{no}$ & $1.78 \pm 0.01$ \\
\hline HI 26 & $\mathrm{M} / 53$ & macro/no & $0.50 \pm 0.06$ \\
\hline HI 27 & $\mathrm{M} / 34$ & $\mathrm{macro} / \mathrm{no}$ & $0.93 \pm 0.06$ \\
\hline
\end{tabular}

a Tumors larger than $1 \mathrm{~cm}$ in diameter were designated as macroadenomas.

b Positive invasion indicates tumor extension within the cavernous sinus and/or the sphenoid sinus.

c Basal VEGF secretion in vitro expressed as $\mathrm{pg} / 1,000$ cells/24 h. nd $=$ Not detectable.

$20 \mathrm{mg} / \mathrm{l}$ sodium selenium, essential amino acids and minimal essential vitamins. The cells were grown at $37^{\circ} \mathrm{C}$ with $5 \% \mathrm{CO}_{2}$ in a humid incubator.

\section{Primary Cell Culture of Pituitary Adenomas}

Pituitary adenoma cell culture was performed as previously described [34]. In brief, the tumors where washed and then treated for approximately $1 \mathrm{~h}$ with collagenase at $37^{\circ} \mathrm{C}$ followed by mechanical agitation. Once the tumor had been dissociated the resultant cells where washed by repeated centrifugation. The pellet was resupended in medium and the cell counts and viability determined using acridine orange and ethidium bromide. 100,000 cells per well were plated into 48-well plates and cultivated in $0.5 \mathrm{ml} /$ well of $D$ Val-MEM medium (pH 7.3) supplemented with $10 \%$ FCS, $2.2 \mathrm{~g} / 1$ $\mathrm{NaHCO}_{3}, 10 \mathrm{~m} M$ HEPES, $2 \mathrm{~m} M$ glutamine, $10^{5} \mathrm{U} / 1$ penicillin-streptomyocin, $2.5 \mathrm{mg} / \mathrm{l}$ amphotericin, $30 \mathrm{p} M$ tri-iodothyronine, $5 \mathrm{mg} / \mathrm{l}$ transferrin, $20 \mu \mathrm{g} / \mathrm{l}$ sodium selenium, essential amino acids and min-
Table 2. Characteristics of clinically hormone active somatotrope (S1-S21), corticotrope (C1-C9) and lactotrope (L1-L3) pituitary adenomas

\begin{tabular}{|c|c|c|c|}
\hline Tumor & Sex/age & Size $^{a} /$ invasive $^{b}$ & $\mathrm{VEGF}^{\mathrm{c}}$ \\
\hline S 1 & $F / 26$ & macro/yes & $1.16 \pm 0.06$ \\
\hline S 2 & $\mathrm{M} / 31$ & macro/yes & $5.02 \pm 0$ \\
\hline S 3 & $\mathrm{~F} / 55$ & macro/yes & $0.87 \pm 0.05$ \\
\hline S 4 & $\mathrm{M} / 35$ & macro/yes & $1.02 \pm 0.05$ \\
\hline S 5 & $\mathrm{~F} / 45$ & macro/no & $3.42 \pm 0.18$ \\
\hline S 6 & $\mathrm{~F} / 42$ & macro/yes & $0.09 \pm 0$ \\
\hline S 7 & $\mathrm{M} / 32$ & micro/no & $0.18 \pm 0.01$ \\
\hline S 8 & $\mathrm{M} / 19$ & macro/no & $1.29 \pm 0.11$ \\
\hline S 9 & $\mathrm{~F} / 52$ & macro/no & $0.52 \pm 0.04$ \\
\hline S 10 & $\mathrm{~F} / 35$ & macro/yes & $1.36 \pm 0.15$ \\
\hline S 11 & $\mathrm{M} / 29$ & macro/no & $0.40 \pm 0.07$ \\
\hline S 12 & $\mathrm{~F} / 65$ & macro/yes & nd \\
\hline S 13 & $\mathrm{M} / 64$ & micro/no & nd \\
\hline S 14 & $\mathrm{M} / 28$ & macro/yes & nd \\
\hline S 15 & $\mathrm{M} / 23$ & micro/no & $0.28 \pm 0.02$ \\
\hline S 16 & $\mathrm{M} / 55$ & macro/no & $0.23 \pm 0.11$ \\
\hline S 17 & $\mathrm{~F} / 48$ & micro/no & $1.06 \pm 0.004$ \\
\hline S 18 & $\mathrm{~F} / 58$ & $\mathrm{micro} / \mathrm{no}$ & nd \\
\hline S 19 & $\mathrm{~F} / 70$ & macro/no & $0.53 \pm 0.06$ \\
\hline S 20 & $\mathrm{~F} / 67$ & micro/no & $0.78 \pm 0.12$ \\
\hline S 21 & $\mathrm{~F} / 52$ & macro/yes & $0.26 \pm 0.02$ \\
\hline $\mathrm{C} 1$ & $F / 24$ & micro/no & $0.43 \pm 0.03$ \\
\hline $\mathrm{C} 2$ & $F / 21$ & $\mathrm{micro} / \mathrm{no}$ & $1.83 \pm 0.08$ \\
\hline C 3 & $F / 22$ & $\mathrm{micro} / \mathrm{no}$ & $0.05 \pm 0.004$ \\
\hline $\mathrm{C} 4$ & $\mathrm{~F} / 33$ & micro/no & $0.08 \pm 0.02$ \\
\hline C 5 & M/29 & $\mathrm{micro} / \mathrm{no}$ & $1.18 \pm 0.08$ \\
\hline $\mathrm{C} 6$ & $\mathrm{~F} / 54$ & micro/no & $0.05 \pm 0.004$ \\
\hline C 7 & $\mathrm{~F} / 38$ & $\mathrm{micro} / \mathrm{no}$ & $0.11 \pm 0.01$ \\
\hline C 8 & $\mathrm{M} / 45$ & micro/no & $0.21 \pm 0.03$ \\
\hline C 9 & $\mathrm{~F} / 41$ & macro/no & $0.45 \pm 0.06$ \\
\hline L1 & $F / 25$ & macro/no & $12.73 \pm 0.88$ \\
\hline L 2 & $\mathrm{~F} / 43$ & macro/no & $0.73 \pm 0.03$ \\
\hline L 3 & M/29 & $\mathrm{macro} / \mathrm{no}$ & $0.03 \pm 0.004$ \\
\hline
\end{tabular}

a Tumors larger than $1 \mathrm{~cm}$ in diameter were designated as macroadenomas.

b Positive invasion indicates tumor extension within the cavernous sinus and/or the sphenoid sinus.

c Basal VEGF secretion in vitro expressed as pg/1,000 cells/24 h. nd $=$ Not detectable.

imal essential vitamins. $D$-Val-MEM medium was used to suppress growth of fibroblasts [34].

\section{Stimulation and VEGF Determination}

When the tumor cell lines were nearly confluent, or in case of the adenoma cell cultures 2 days after plating, the cells were washed once with phosphate-buffered saline (PBS) and then pretreated for $24 \mathrm{~h}$ in the appropriate cell culture medium without FCS $(0.5 \mathrm{ml}$ medium per well). Following the pretreatment period, the cells were treated in 


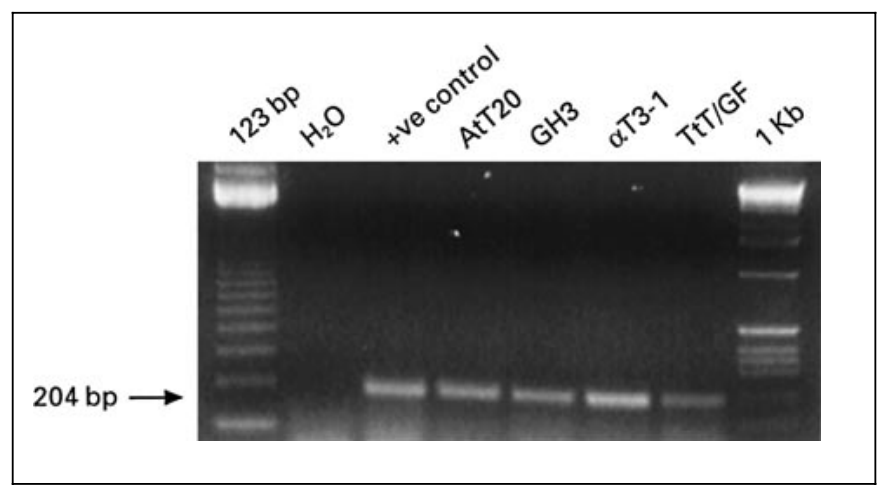

Fig. 1. VEGF mRNA detected by nonquantitative RT-PCR in pituitary tumor cell lines (AtT20, GH3, aT3-1, TtT/GF) and in fetal mouse tissue (+ve control). The expected $204 \mathrm{~kb}$ cDNA band is visualized by ethidium bromide staining. In the absence of specific primers $\left(\mathrm{H}_{2} \mathrm{O}\right)$ no $P C R$ product was present.

triplicate with the following substances diluted in fresh serum-free medium ( $0.5 \mathrm{ml} /$ well): $10^{-9}$ to $10^{-6} M$ dexamethasone or bromocriptine, $10^{-10}$ to $10^{-7} M$ E2, $10^{-9}$ to $10^{-7} M$ PACAP-38, ocreotide or TGF- $\alpha, 0.1$ to $10 \mathrm{ng} / \mathrm{ml}$ IL- 6 and $0.2 \mathrm{ng} / \mathrm{ml}$ to $20 \mathrm{ng} / \mathrm{ml}$ IGF-I. Cells were treated with the substances for $24 \mathrm{~h}$ since no short-term stimulation of VEGF was observed in a previous study [31]. The supernatant $(0.5 \mathrm{ml})$ was then collected from the wells and the secreted VEGF isoforms, among them the dominating human VEGF165 or mouse/ rat VEGF164, were measured in terms of $\mathrm{pg} / \mathrm{ml}$ using specific ELISA assay kits for human and mouse/rat VEGF (R\&D Systems, Wiesbaden, Germany) [31], respectively. The detection limit of the VEGF ELISA was $3 \mathrm{pg} / \mathrm{ml}$ for both mouse/rat and human VEGF. Intra- and inter-assay coefficients were 4.7 and $6.4 \%$ for the mouse/rat VEGF ELISA and 5.1 and $7.3 \%$ for the human VEGF ELISA. To exclude the possibility that variations in the concentration of VEGF (measured as $\mathrm{pg} / \mathrm{ml}$ ) in the cell culture supernatants might reflect variations in cell number, the cells in each well were counted and VEGF secretion was calculated as pg per 1,000 cells per $24 \mathrm{~h}$.

\section{Cell Counts}

The cell monolayers were treated for 5-10 min with $400 \mu$ l tryp$\sin /$ EDTA at $37^{\circ} \mathrm{C}$, the enzymatic reaction was stopped with $100 \mu \mathrm{l}$ FCS, and the number of cells were determined as previously described [35] in each well using an adapted Coulter counter.

Reverse Transcription-Polymerase Chain Reaction (RT-PCR)

For RT-PCR, total cellular RNA was isolated from the cell lines and from mouse fetal tissue by guanidinium isothiocyanate followed by the phenol-chloroform method [36]. For VEGF mRNA detection, the $\mathrm{C}$ therm. polymerase one-step RT-PCR kit (Roche Molecular Biochemicals, Mannheim, Germany) was used following the manufacturer's instructions. In brief, a mixture of $0.4 \mathrm{~m} M$ of each deoxynucleoside triphosphate, 7\% dimethylsulfoxide (DMSO), $5 \mathrm{mM}$ dithiothreitol (DTT), $20 \mathrm{U}$ RNase inhibitor, $2 \mu M$ sense and $2 \mu M$ antisense VEGF primer and $1 \mu \mathrm{g}$ total cellular RNA in a final volume of $25 \mu \mathrm{l}$ was carefully mixed on ice with $25 \mu \mathrm{l}$ of a solution containing $\mathrm{C}$ therm. polymerase in RT-PCR buffer. The mixture was then placed in a thermocycler (Techne, Cambridge, UK) to perform reverse transcription at $64^{\circ} \mathrm{C}$ for $30 \mathrm{~min}$ followed by a 35 -cycle PCR, each cycle consisting of denaturation at $94^{\circ} \mathrm{C}$ for $45 \mathrm{~s}$, annealing of primers at $60^{\circ} \mathrm{C}$ for $45 \mathrm{~s}$, and chain extension at $72^{\circ} \mathrm{C}$ for $1 \mathrm{~min}$. Amplified products were electrophoresed in $1.8 \%$ agarose gel and stained with ethidium bromide.

Specific primers to detect murine VEGF mRNA were constructed according to the published DNA sequence [36] (GenBank accession number: S38100). The VEGF primers ( $5^{\prime}$ primer: $5^{\prime}$-CCT GGT GGA CAT CTT CCA GGA GTA CC-3'; 3'primer: 5'-TGT GCT GTA GGA AGC TCA TC-3') generated a PCR amplification product of $204 \mathrm{bp}$ in length.

\section{Statistics}

The individual experiments were performed with triplicate wells and analysis of variance (ANOVA) in combination with Scheffe's test was used for statistics. The data are expressed as mean \pm SE. Differences between the tumor types were assessed using the Mann-Whitney U test.

\section{Results}

\section{VEGF Secretion and Regulation in Pituitary Tumor Cell Lines}

All four cell lines synthesized VEGF mRNA as demonstrated by RT-PCR (fig. 1) and basally secreted VEGF protein. The highest VEGF production expressed in terms of pg/1,000 cells/24 h was observed in AtT20 cells $(2.43 \pm 1.07)$ followed by TtT/GF cells $(1.51 \pm 0.71)$, and then GH3 cells $(0.36 \pm 0.10)$, and finally $\alpha \mathrm{T} 3-1$ cells $(0.21 \pm 0.04)$ which produced the least. The relatively high SE values are due to the fact that basal VEGF secretion data were pooled from different experiments performed with different batches or passages of the cell lines. VEGF secretion values for the individual experiments indicated below, and shown in figures 2 and 3, mostly exhibited SE values of less than $15 \%$ of the mean.

Dexamethasone dose-dependently inhibited VEGF in AtT20, GH3 and TtT/GF cells, but had no effect on basal VEGF production in aT3-1 (fig. 2). Half-maximal inhibition of VEGF secretion was achieved with $10^{-8} M$ dexamethasone. Maximum inhibitory effects on VEGF production were induced by $10^{-7} M$ dexamethasone whereas $10^{-6} M$ dexamethasone did not further significantly inhibit VEGF release. The glucocorticoid receptor antagonist RU486 reversed the inhibitory action of dexamethasone confirming the specificity of the glucocorticoid inhibition of VEGF production.

Figure 3 summarizes the response of VEGF to other stimuli tested in rodent pituitary cell lines. Although dose response studies have been performed for all the test substances in all of the cell lines, only the effects of the maximum concentrations of the stimuli are shown. VEGF 
Fig. 2. Suppression of VEGF production by dexamethasone in pituitary tumor cell lines. Dexamethasone dose-dependently inhibited VEGF secretion in folliculostellate TtT/GF cells (a), corticotrope AtT20 cells (b), and lactosomatotrope $\mathrm{GH} 3$ cells (c), whereas VEGF production by gonadotrope $\alpha \mathrm{T} 3-1$ cells was not affected. The glucocorticoid receptor antagonist RU486 $\left(10^{-7} \mathrm{M}\right)$ itself did not affect VEGF inhibitory action of $10^{-8} M$ dexamethasone. Treatment period was $24 \mathrm{~h}$ in all experiments. Values (mean \pm SE) are expressed as \% of basal $(=100 \%)$ secretion. ${ }^{*} \mathrm{p}<0.05 ;{ }^{* *} \mathrm{p}<0.01 ; * * * \mathrm{p}<$ 0.001 .

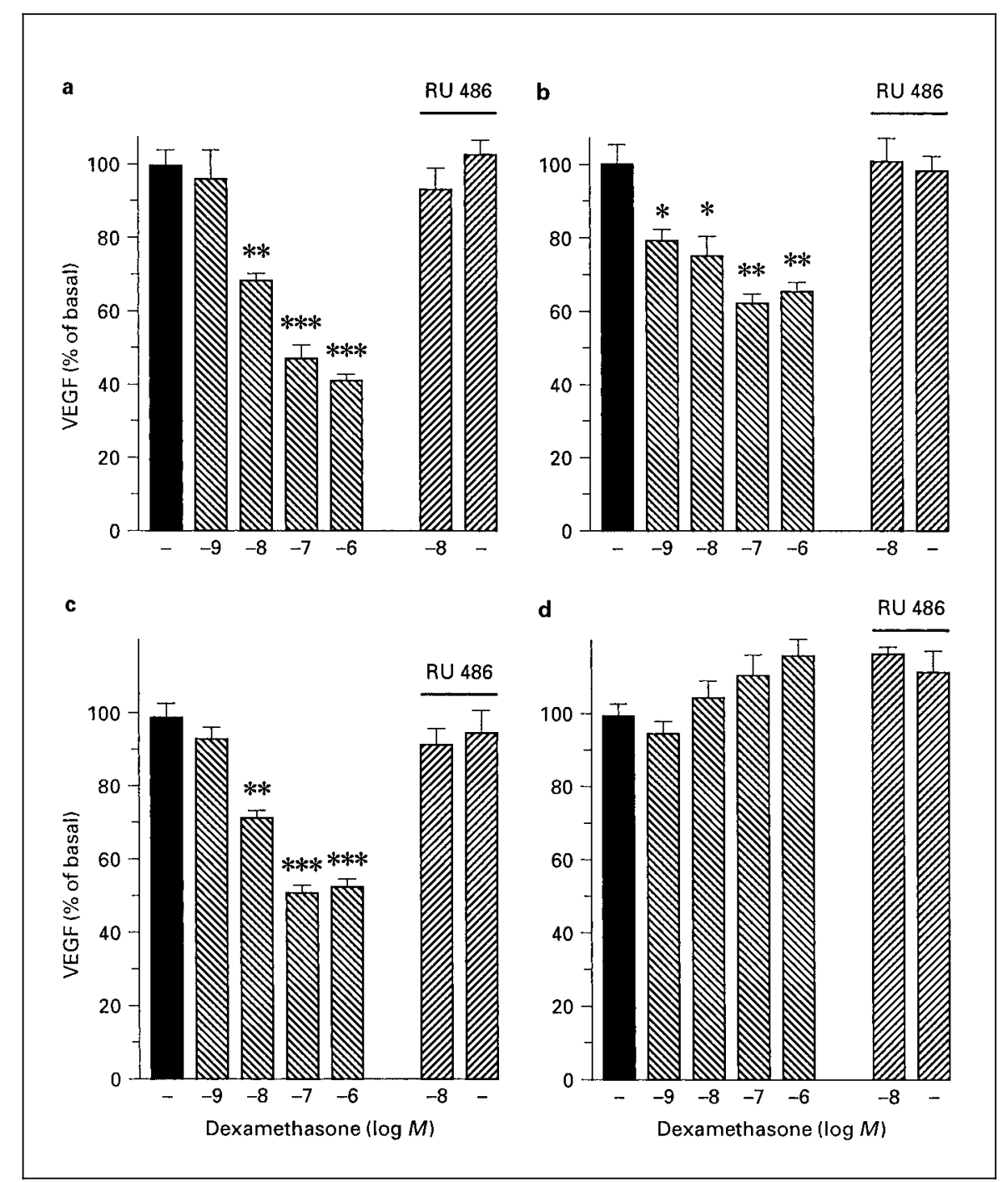

secretion by the endocrine pituitary cell lines ( $\alpha \mathrm{T} 3-1$, AtT20 and GH3 cells) was not affected by any stimuli tested as only a few substances slightly, but not significantly, inhibited or stimulated VEGF production in some of the endocrine pituitary tumor cell lines (fig. 3). Treatment of GH3, AtT20 and $\alpha$ T3-1 cells with $10^{-9}$ to $10^{-7} M$ TRH, CRH and LHRH did not affect basal VEGF secretion (data not shown).

However, TtT/GF cells were remarkably responsive to stimulation. PACAP-38 $\left(10^{-7} M\right)$ and IL-6 $(10 \mathrm{ng} / \mathrm{ml})$ strongly augmented VEGF levels to $339 \pm 69 \%$ and 178 $\pm 23 \%$ of basal, respectively (fig. 3a, d). Dose-dependent stimulation of VEGF production by PACAP and IL-6 in TtT/GF cells has already been shown in a previous study [31] and, therefore, is not documented again in the present manuscript. Significant increases in VEGF secretion were also observed after stimulating TtT/GF cells with $20 \mathrm{ng} / \mathrm{ml}$ IGF-I $(173.4 \pm 13.4 \%$; fig. $2 \mathrm{c}), 10^{-7} \mathrm{M}$ TGF- $\alpha(161.2 \pm 17.0 \%$; fig. $2 \mathrm{f})$ and $10^{-7} M$ octreotide (168.9 $\pm 9.0 \%$; fig. $2 \mathrm{e})$. Lower concentrations of these 3 substances, slightly but not significantly, stimulated VEGF secretion by TtT/GF cells. Both bromocriptine and E2 did not affect VEGF production by TtT/GF cells at any concentration tested.

\section{VEGF Secretion and Regulation in Human Pituitary Adenoma Cell Cultures}

Basal VEGF levels for each tumor are presented in tables 1 and 2. In vitro, all 9 corticotrope tumors and all 3 prolactinomas produced basal VEGF, whereas 1 of the 27 

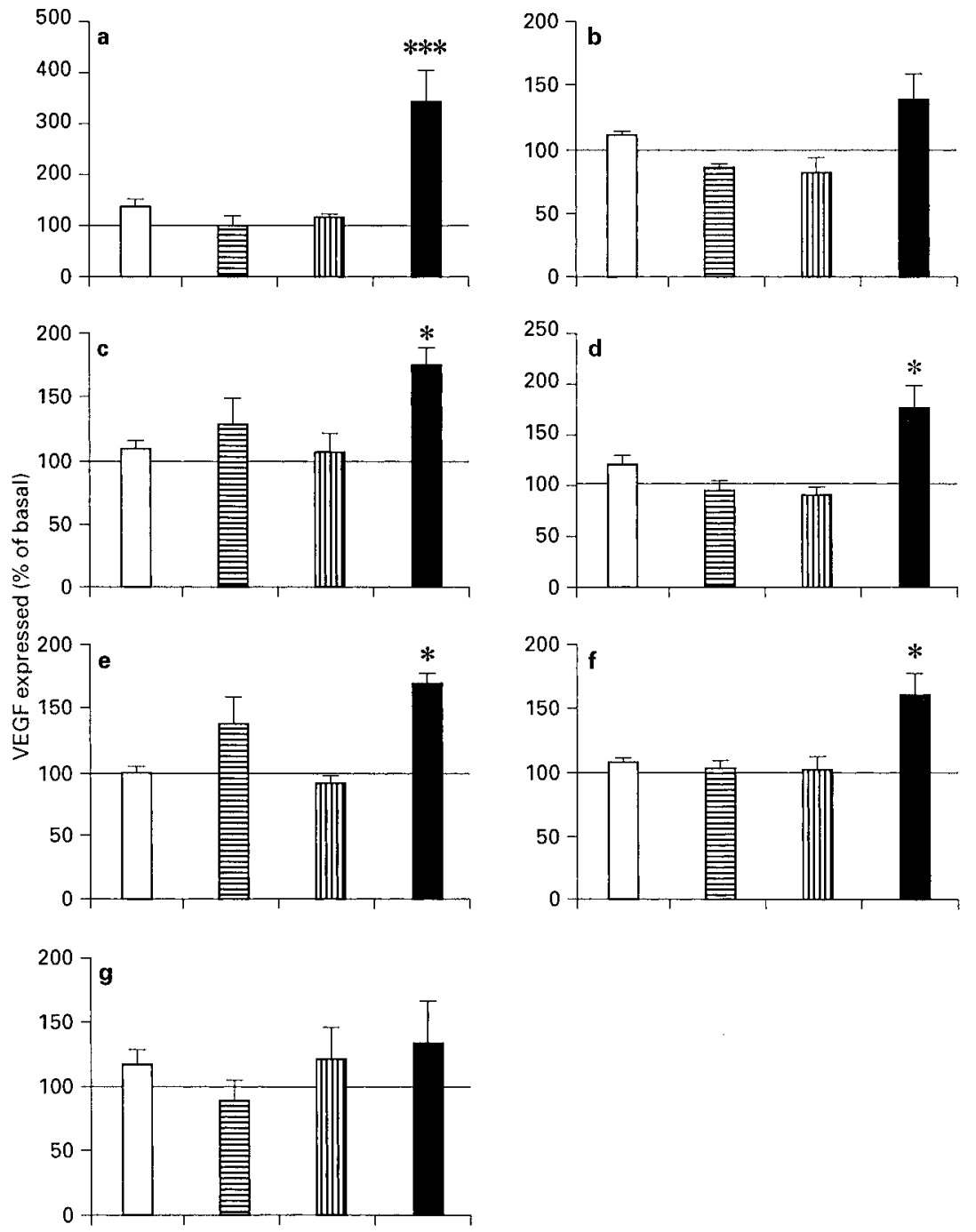

Fig. 3. Regulation of VEGF release from gonadotrope $\alpha \mathrm{T} 3-1$ cells (open bars), corticotrope AtT20 cells (horizontal stripes), Lactosomatotrope GH3 cells (vertical stripes) and folliculostellate TtT/GF cells (black bars). Cells were treated for $24 \mathrm{~h}$ with stimuli at different concentrations as indicated in 'Materials and Methods', but only the VEGF values in response to $10^{-7} M$ PACAP-38 (a), $10^{-6} M$ bromocriptine (b), $20 \mathrm{ng} / \mathrm{ml} \mathrm{IGF-I} \mathrm{(c),} 10 \mathrm{ng} / \mathrm{ml} \mathrm{IL-6} \mathrm{(d),} 10^{-7}$ $M$ octreotide (e), $10^{-7} M$ TGF- $\alpha(\mathbf{f})$, and $10^{-7} M$ 17 $\beta$-estradiol (g) are shown. Values (mean \pm SE) are expressed as $\%$ of basal $(=100 \%)$ VEGF secretion. $* \mathrm{p}<0.05 ; * * * \mathrm{p}<0.001$.

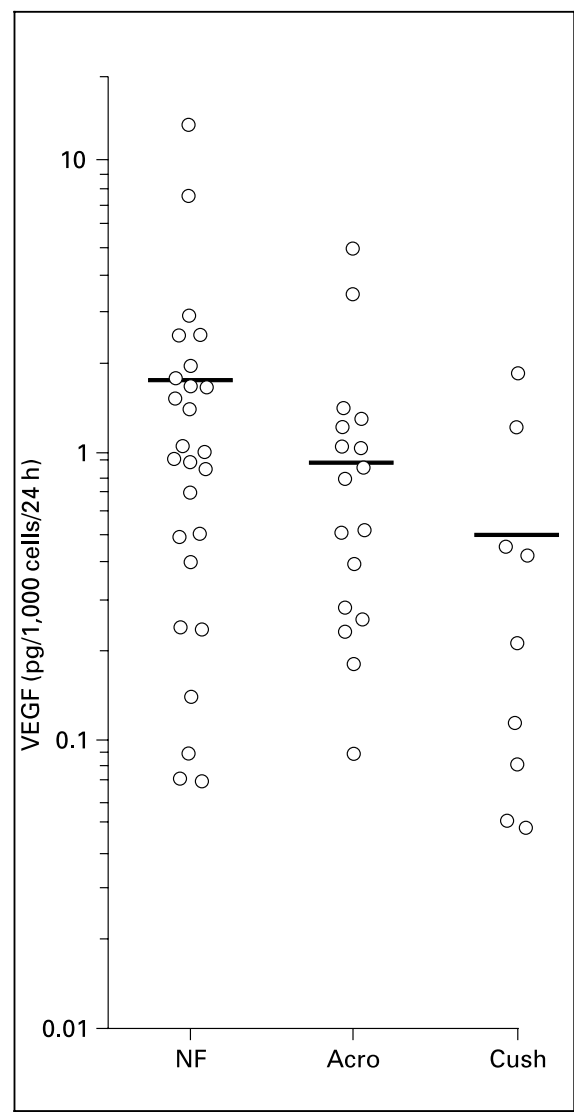

Fig. 4. Comparison of the basal VEGF production (expressed as ng VEGF per 1,000 cells per $24 \mathrm{~h}$; see tables 1 and 2 ) by nonfunctioning (NF), somatotrope (Acro) and corticotrope (Cush) pituitary adenomas. VEGF values for prolactinomas have been excluded in this figure since too few cases with extremely heterogeneous basal VEGF secretion had been studied (table 2). The mean VEGF values of the individual tumor cell cultures are shown without SE bars. Differences in the VEGF production among the different adenoma types were not significant. hormone inactive adenomas (4\%) and 4 of the 21 somatotrope tumors $(19 \%)$ had no detectable basal VEGF. The mean basal VEGF values for the hormone inactive, somatotrope and corticotrope tumors (too few lactotrope adenomas were studied to perform appropriate statistics) were $1.74 \pm 0.54,0.88 \pm 0.27$ and $0.49 \pm 0.21 \mathrm{pg} / 1,000$ cells/24 h, respectively (fig. 4). However, due to the wide range in values between the individual tumors, there was no significant difference between the different tumor types. Furthermore, no significant differences in the basal VEGF secretion were found between micro- and macroadenomas or between invasive and noninvasive tumors (data not shown). 
Fig. 5. Suppression of VEGF production by dexamethasone in human pituitary adenoma cultures. Results of three representative tumor cell cultures (somatotrope adenoma $\mathrm{S} 9$, corticotrope adenoma $\mathrm{C} 2$ and hormoneinactive adenoma HI11), in which VEGF secretion was dose-dependently inhibited by dexamethasone during a 24-hour treatment period, are shown. ${ }^{*} \mathrm{p}<0.05 ;{ }^{* *} \mathrm{p}<0.01$; $* * * \mathrm{p}<0.001$

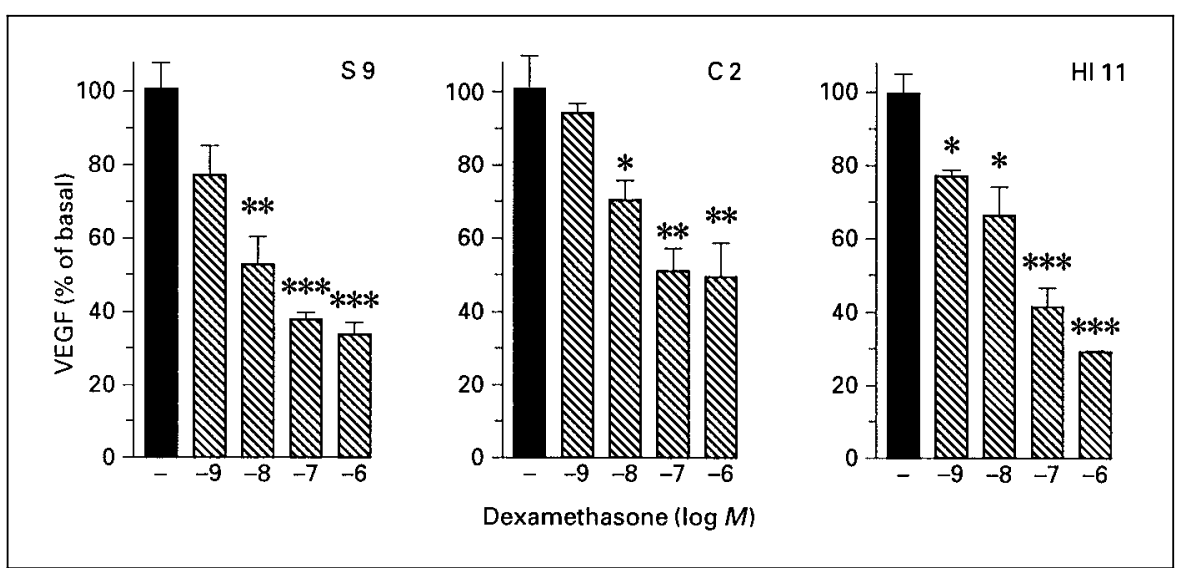

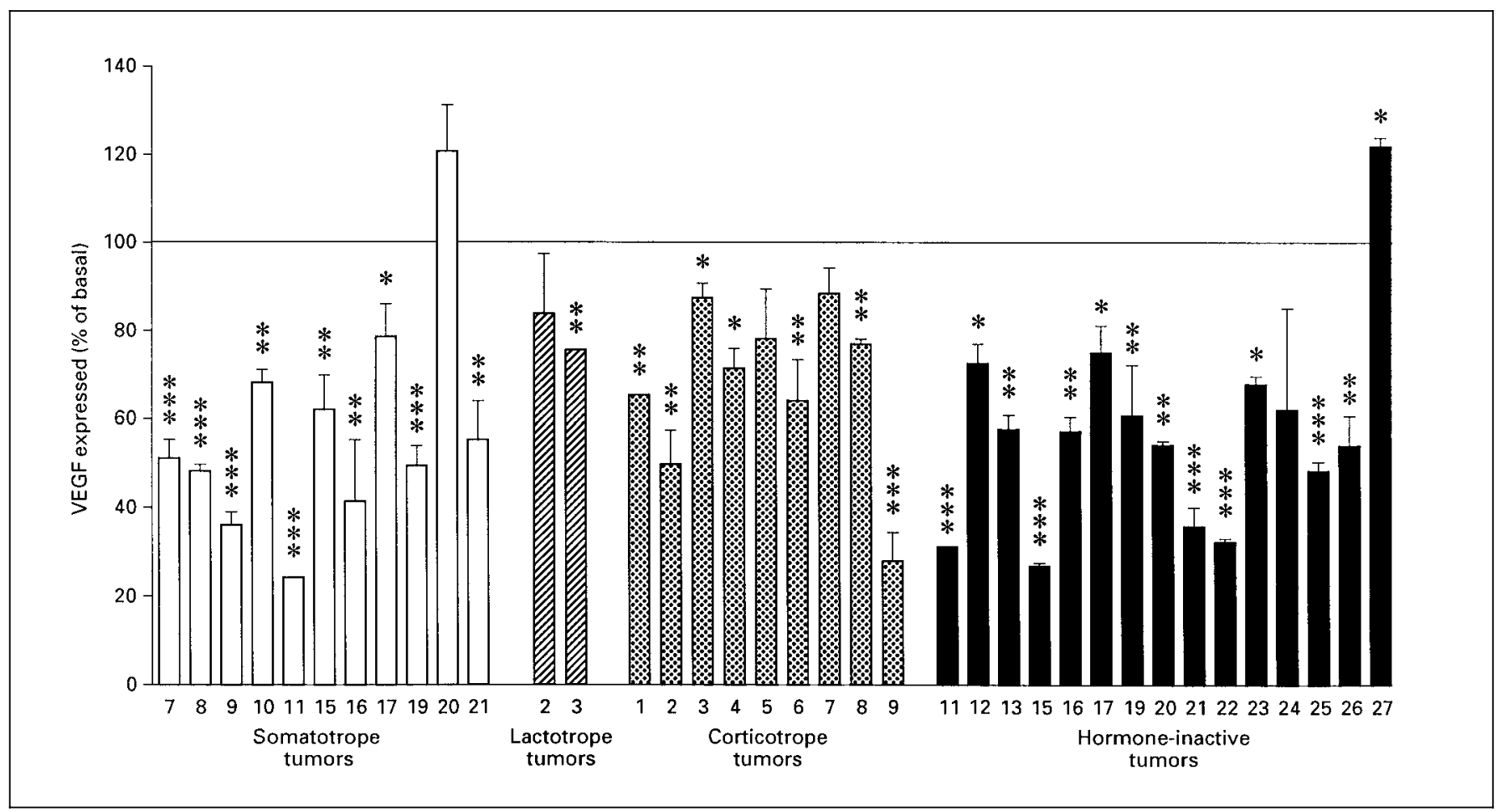

Fig. 6. Effect of dexamethasone $\left(10^{-6} M\right)$ on VEGF secretion by pituitary adenoma cell cultures. Cells were treated for $24 \mathrm{~h}$. Values (mean $\pm \mathrm{SE}$ ) are expressed as $\%$ of basal $(=100 \%)$. ${ }^{*} \mathrm{p}<0.05 ; * * \mathrm{p}<0.01 ;{ }^{* * *} \mathrm{p}<0.001$.

In the results of the stimulation experiments which are shown in figures 5 and 6 and in table 3, only the tumors which had measurable VEGF are taken into consideration. Since basal VEGF secretion by the tumors was extremely heterogeneous, values are expressed as $\%$ of basal $(=100 \%)$. Due to the limited amount of tumor tissue available, in most cases VEGF stimulation tests could not be performed with all stimuli in parallel. Because rodent pituitary cell lines were most responsive to glucocorticoid treatment, the effect of dexamethasone on VEGF secretion was studied in as many pituitary adenomas as possible. In about half of the tumors treated with dexamethasone, dose-response studies were performed (representative results are shown in figure 5) whereas the 
Table 3. Alterations in VEGF production (\% of basal) by human pituitary adenoma cell cultures in response to different stimuli

\begin{tabular}{lcccc}
\hline \multirow{2}{*}{ Stimulus } & \multicolumn{3}{l}{ Adenomas } & \\
\cline { 2 - 5 } & hormone inactive & somatotrope & prolactinoma & corticotrope \\
\hline IL-6 $(10 \mathrm{ng} / \mathrm{ml})$ & $90.4 \pm 7.8(10)$ & $101.4 \pm 14.5(5)$ & $106.0(1)$ & $119.1 \pm 12.7(5)$ \\
PACAP-38 $\left(10^{-1} M\right)$ & $107.0 \pm 16.5(6)$ & $138.7 \pm 10.4(3)^{*}$ & $126.1 \pm 18.9(2)$ & $103.3(1)$ \\
IGF-I $(20 \mathrm{ng} / \mathrm{ml})$ & $103.5 \pm 8.3(3)$ & $109.4 \pm 12.1(10)$ & $108.8 \pm 6.2(2)$ & $113.7 \pm 4.9(3)$ \\
Octreotide $\left(10^{-7} M\right)$ & $95.7 \pm 2.5(2)$ & $98.5 \pm 16.7(6)$ & $93.7(1)$ & $102.8 \pm 12.1(4)$ \\
Bromocriptine $\left(10^{-6} M\right)$ & $122.9 \pm 11.1(5)$ & $116.5 \pm 14.0(4)$ & $93(1)$ & $110(1)$ \\
E2 $\left(10^{-7} M\right)$ & $110.2 \pm 12.0(7)$ & $87.8 \pm 28.1(3)$ & $141.8 \pm 4.8(2)^{* *}$ & - \\
TGF- $\alpha\left(10^{-7} M\right)$ & $136.7 \pm 8.7(7)^{* *}$ & $116.8 \pm 8.0(6)$ & $120(1)$ & $127.7 \pm 28.2(3)$ \\
\hline$* \mathrm{p}<0.05, * * \mathrm{p}<0.01$. & & & & \\
\hline
\end{tabular}

remaining adenomas were treated only with two concentrations $\left(10^{-8} M, 10^{-6} M\right)$ or the highest dose of dexamethasone. Figure 6 summarizes the VEGF response to treatment with $10^{-6} \mathrm{M}$ dexamethasone, which significantly inhibited VEGF release in 31 of 37 adenomas (84\%). Results from dose-response studies in dexamethasoneresponsive adenoma cell cultures showed a similar VEGF-inhibitory pattern (fig. 5) as observed in pituitary tumor cell lines.

Most of the other stimuli tested, did not affect VEGF secretion in different types of adenomas. Average VEGF secretion values are listed in table 3 .

Only in the hormone inactive tumors did TGF- $\alpha$ significantly increase basal VEGF levels to $136.7 \pm 8.7 \%$ $(\mathrm{p}<0.01, \mathrm{n}=7)$. However, although TGF- $\alpha$ enhanced VEGF secretion in all these tumors, only in 4 of 7 were the increases significant. Two of 3 of the somatotrope tumors treated with PACAP-38 had significantly elevated levels of VEGF. The mean of PACAP-induced VEGF production, expressed as $\%$ of basal, was $138.7 \pm 10.4(\mathrm{p}<0.05)$. E2 significantly increased VEGF levels in the prolactinomas $(141.8 \pm 4.8 \% ; \mathrm{p}<0.01)$. Both tumors tested responded to E2 with significantly enhanced production of VEGF.

Apart from the tumor types indicated above, TGF- $\alpha$, PACAP-38 and E2 did not affect VEGF production by any other adenoma type. Octreotide, bromocriptine, IL-6 and IGF-I had no significant effect on VEGF secretion in all adenoma types (table 3 ).

\section{Discussion}

Although pituitary adenomas are normally less well vascularized than normal anterior pituitary [37], there is no doubt that neovascularization is essential for pituitary tumor formation. In the present work the secretion and regulation of the most potent angiogenic factor, VEGF, was studied for the first time in pituitary tumor cell lines and a large number of pituitary adenomas in vitro. Whereas in normal pituitary VEGF has been reported to be produced only by FS cells [23, 24], it seems that during transformation endocrine pituitary tumor cells acquire the ability to produce VEGF, since in contrast to the corresponding normal endocrine cell types, corticotrope AtT20 and lactosomatotrope GH3 pituitary tumor cell lines basally synthesized and released VEGF. Since FS cells are rarely found in adenomas (see below) and because intratumoral endothelial cells represent a target but not a source of VEGF within solid tumors [6], pituitary adenoma cells seem to be responsible for VEGF production in the pituitary tumor cell cultures. Although the source of VEGF in adenomas needs to be identified more precisely in future studies, our results suggest that endocrine pituitary tumor cells may be involved in the angiogenetic process, which is essential for tumor progression.

Rodent endocrine pituitary cell lines (AtT20, GH3, $\alpha \mathrm{T} 3-1)$ and human pituitary adenoma cells produced extremely variable amounts of VEGF under basal conditions. However, in vitro VEGF production by human adenoma cells did not correlate with size or the invasive character of the tumors. None of the substances that are clinically used to suppress expansion of some types of pituitary adenomas, such as the somatostatin analogue

\footnotetext{
$\overline{102} \quad$ Neuroendocrinology 2001;74:95-105
} 
octreotide, or the dopamine agonist bromocriptine, inhibited VEGF production in any of the adenoma types or endocrine cell lines tested, although the presence of functional receptors in these tumors or cell lines has previously been demonstrated [32-34, 38-41]. This indicates that these compounds do not mediate tumor shrinkage via suppression of VEGF-driven angiogenesis.

In contrast, as has already been shown in other types of solid tumors [42, 43], glucocorticoids can have an antiangiogenic property since in most human adenomas $(84 \%)$ as well as in AtT20 and GH3 cell lines VEGF release was suppressed by dexamethasone. Our observation that glucocorticoids are potent inhibitors of VEGF production in vitro is highly relevant especially with respect to corticotrope adenoma development in vivo. Since serum cortisol levels are elevated in patients with Cushing's disease, VEGF production and the subsequent angiogenesis in the corticotrope adenomas could be suppressed in vivo. This could be one explanation for the microadenomatous phenotype of these tumors. On the other hand, the development of large corticotrope Nelson tumors after bilateral adrenalectomy may in part be a consequence of enhanced angiogenesis due to the removal of the inhibitory influence of glucocorticoids on VEGF production.

Autonomous VEGF production by endocrine pituitary cell lines and adenoma cells was poorly stimulated. PACAP-38 was found to stimulate VEGF production by somatotrope adenoma cells and TGF- $\alpha$ enhanced VEGF release from nonfunctioning tumor cells, indicating that these factors might play a role in some types of adenomas. However, since only a few adenomas were studied, more work is needed to confirm this hypothesis. Neither IGF-I that is enhanced in patients with somatotrope adenomas, nor IL-6 that is known to stimulate VEGF production in some types of tumor cells [44] and is intrinsically produced by many pituitary adenomas [45-47], were able to stimulate VEGF production by pituitary adenoma cells.

In contrast to adenoma cells, VEGF production by folliculostellate TtT/GF pituitary cells was strongly enhanced by PACAP-38, TGF- $\alpha$, IL- 6 and IGF-I. Therefore, these substances probably affect pituitary adenoma vascularisation by another mechanism in which FS cells play an important role. FS cells are not or only rarely found in pituitary adenomas but accumulate in a transition zone at the boundary of the tumors [48-50]. It is possible that during tumorigenesis substances that are produced by tumor cells themselves (IL-6, TGF- $\alpha$ ) [45-47, $51,52]$, or by the hypothalamus (PACAP-38), or that are elevated in the blood (IGF-I in acromegalic patients) may stimulate VEGF production by FS cells within this transition region. The FS cell-derived VEGF could then diffuse, or be carried in the blood supply, to the tumor where it could cause the generation of new blood vessels. Therefore, during initiation of tumor formation, and especially in microadenomas, the edge of the adenoma could represent the major site of initiation and regulation of angiogenesis. This concept is similar to the model proposed by Fukumara et al. [53] where they speculated that fibroblasts on the tumor periphery are the most important source of VEGF during formation of some types of tumors.

High estrogen levels are considered to be responsible for pituitary hyperplasia in pregnant females and are thought to be involved in prolactinoma development [54]. We could not confirm a previous report that E2 stimulates VEGF production by lactosomatotrope GH3 cells [28], but we have been able to demonstrate that E2 augments VEGF levels in prolactinoma tumor cell preparations. This could be part of the mechanism by which estrogen causes pituitary hyperplasia and prolactinoma formation. Our observation is in agreement with the findings of Banerjee et al. [29] who demonstrated in vivo that estrogen stimulates VEGF production, and increases VEGF receptors expression during estrogen-induced prolactinoma formation in Fischer 344 rats. However, VEGF regulation by $\mathrm{E} 2$ needs to be studied in more lactotrope adenomas, to confirm our speculation that E2 is involved in prolactinoma neovascularisation.

In summary, we have demonstrated that pituitary adenoma cells produce extremely variable amounts of VEGF in vitro. The heterogeneity in VEGF production by pituitary adenomas might reflect the degree of intratumoral vessel formation which may correlate with the dynamics of pituitary tumor progression. Our results concerning the suppression of VEGF by dexamethasone suggest that glucocorticoids may have anti-angiogenic properties and, therefore, therapeutic benefit in the treatment of some types of pituitary adenoma.

\section{Acknowledgment}

This work was supported by a grant from the DFG: RE 851/1-1. 


\section{References}

1 Elias KA, Weiner RI: Direct arterial vascularization of estrogen-induced prolactin-secreting anterior pituitary tumors. Proc Natl Acad Sci USA 1984;81:4549-4553.

2 Gorczyca W, Hardy J: Microadenomas of the human pituitary and their vascularization. Neurosurgery 1988;22:1-6.

3 Schechter J, Goldsmith P, Wilson C, Weiner R: Morphological evidence for the presence of arteries in human prolactinomas. J Clin Endocrinol Metab 1988;67:713-719.

4 Kim K, Li B, Winer J, Armanini M, Gillett N, Phillips $\mathrm{H}$ : Inhibition of vascular endothelial growth factor-induced angiogenesis suppresses tumour growth in vivo. Nature 1993;362:841844.

5 Yuan F, Chen Y, Dellian M, Safabaksh N, Ferrara N, Jain RK: Time-dependent vascular regression and permeability changes in established human xenografts induced by anti-vascular endothelial growth factor/vascular permeability factor antibody. Proc Natl Acad Sci USA 1996;93:14765-14770.

6 Ferrara N, Davis-Smyth T: The biology of vascular endothelial growth factor. Endocr Rev 1997; 18:4-25.

7 Pertovaara L, Kaipainen A, Mustonen T, Orpana A, Ferrara N, Saksela O, Alitalo K: Vascular endothelial growth factor is induced in response to transforming growth factor- $\beta$ in fibroblastic and epithelial cells. J Biol Chem 1994;269:6271-6274.

8 Ollivier V, Bentolila S, Chabbat J, Hakim J, de Prost D: Tissue factor-dependent vascular endothelial growth factor production by human fibroblasts in response to activated factor VII Blood 1998;91:2698-2703.

9 Franks S, Stallmeyer B, Kämpfer H, Schaffner C, Pfeilschifter J: Differential regulation of vascular endothelial growth factor and its receptor fms-like-tyrosine kinase is mediated by nitric oxide in rat renal mesangial cells. Biochem $\mathrm{J}$ 1999;338:367-374.

10 Detmar M, Yeo KT, Nagy JA, Van de Water L, Brown LF, Berse B, Elicker BM, Ledbetter S, Dvorak HF: Keratinocyte-derived vascular permeability factor (vascular endothelial growth factor) is a potent mitogen for dermal microvascular endothelial cells. J Invest Dermatol 1995;105:44-50.

11 Tischer E, Mitchell R, Hartmann T, Silva M, Gospodarowicz D, Fiddes JC, Abraham JA: The human gene for vascular endothelial growth factor. Multiple protein forms are encoded through alternative exon splicing. J Biol Chem 1991;266:11947-11954.

12 Poltorak Z, Cohen T, Sivan R, Kandelis Y, Spira G, Vlodavsky I, Keshet E, Neufeld G: VEGF145, a secreted vascular endothelial growth factor isoform that binds to the extracellular matrix. J Biol Chem 1997;272:71517158 .
13 Houck KA, Ferrara N, Winer J, Cachianes G, Li B, Leung DW: The vascular endothelial growth factor family: Identification of a fourth molecular species and characterization of alternative splicing of RNA. Mol Endocrinol 1991; 5:1806-1814.

14 Melnyk O, Shuman MA, Kim KJ: Vascular endothelial growth factor promotes tumor dissemination by a mechanism distinct from its effect on primary tumor growth. Cancer Res 1996;56:921-924.

15 Saleh M, Stacker SA, Wilks AF: Inhibition of growth of C6 cells in vivo by expression of antisense vascular endothelial growth factor sequence. Cancer Res 1996;56:393-401.

16 Peters KG, De Vries C, Williams T: Vascular endothelial growth factor receptor expression during embryogenesis and tissue repair suggests a role in endothelial differentiation and blood vessel growth. Dev Biol 1993;90:89158919.

17 Carmeliet P, Ferreira V, Breier G, Pollefeyt S, Kieckens L, Gertsenstein M, Fahrig M, Badenhoeck A, Harpal K, Eberhardt C, Declercq C, Pawling J, Moons L, Collen D, Risau W, Nagy A: Abnormal blood vessel development and lethality in embryos lacking a single VEGF allele. Nature 1996;380:435-439.

18 Ferrara N, Chen H, Davis-Smyth T, Gerber H, Nguyen T, Peers D, Crisholm V, Hillan KJ, Schwall RH: Vascular endothelial growth factor is essential for corpus luteum angiogenesis. Nat Med 1998;4:336-340.

19 Waltenberger J, Claesson-Welsh L, Siegbahn A, Shibuya M, Heldin C: Differential signal transduction properties of KDR and Flt-1, two receptors for vascular endothelial growth factor. J Biol Chem 1994;269:26988-26995.

20 Shalaby F, Rossant J, Yamaguchi TP, Gertsenstein M, Wu X, Breitman ML, Schuh AC: Failure of blood-island formation and vasculogenesis in Flk-1-deficient mice. Nature 1995;376: 62-66.

21 Tsurumi Y, Murohara T, Krasinski K, Chen D, Witzenbichler B, Kearney M, Couffinhal T, Isner JM: Reciprocal relation between VEGF and NO in the regulation of endothelial integrity. Nat Med 1997;3:879-886.

22 Fong G, Rossant J, Gertsenstein M, Breitman ML: Role of the FLT-1 receptor tyrosine kinase in regulating the assembly of vascular endothelium. Nature 1995;376:66-70.

23 Ferrara N, Henzel WJ: Pituitary follicular cells secrete a novel heparin-binding growth factor specific for vascular endothelial cells. Biochem. Biophys. Res. Comm. 1989;161:851-858.

24 Jabbour HN, Boddy SC, Lincoln GA: Pattern and localisation of expression of vascular endothelial growth factor and its receptor flt- 1 in the ovine pituitary gland: Expression is independent of hypothalamic control. Mol Cell Endocrinol 1997;134:91-100.
25 Berkman RA, Merrill MJ, Reinhold WC, Monacci WT, Saxena A, Clark WC, Robertson JT, Ali IU, Oldfield EH: Expression of the vascular permeability factor/vascular endothelial growth factor gene in central nervous system neoplasms. J Clin Invest 1993;91:153-159.

26 Nishikawa R, Cheng S, Nagashima R, Su Huang H, Cavenee WK, Matsutani M: Expression of vascular endothelial growth factor in human brain tumours. Acta Neuropathol 1998; 96:453-462.

27 Plouet J, Schilling J, Gospodarowicz D: Isolation and characterization of a newly identified endothelial cell mitogen produced by AtT-20 cells. EMBO J 1989;8:3801-3806.

28 Ochoa AL, Mitchner NA, Paynter CD, Morris RE, Ben-Jonathan N: Vascular endothelial growth factor in the rat pituitary: Differential distribution and regulation by estrogen. J Endocrinol 2000;165:483-492.

29 Banerjee SK, Sarkar DK, Weston AP, De A, Campbell DR: Over expression of vascular endothelial growth factor and its receptor during the development of estrogen-induced rat pituitary tumors may mediate estrogen-initiated tumor angiogenesis. Carcinogenesis 1997;18: 1155-1161.

30 Heany AP, Horwitz GA, Wang Z, Singson R, Melmed S: Early involvement of estrogeninduced pituitary tumor transforming gene and fibroblast growth factor expression in prolactinoma pathogenesis. Nat Med 1999;5:13171321.

31 Gloddek J, Pagotto U, Paez Pereda M, Arzt E, Stalla GK, Renner U: Pituitary adenylate cyclase-activating polypeptide, interleukin-6 and glucocorticoids regulate the release of vascular endothelial growth factor in pituitary folliculostellate cells. J Endocrinol 1999;160:483490.

32 Renner U, Brockmeier S, Strasburger CJ, Lange M, Schopohl J, Müller OA, von Werder $\mathrm{K}$, Stalla GK: Growth hormone (GH)-releasing peptide stimulation of $\mathrm{GH}$ release from human somatotrope adenoma cells: Interaction with GH-releasing hormone, thyrotropin-releasing hormone, and octreotide. J Clin Endocrinol Metab 1994;78:1090-1096.

33 Stalla GK, Brockmeier SJ, Renner U, Newton C, Buchfelder M, Stalla J, Müller OA: Octreotide exerts different effects in vivo and in vitro in Cushing's disease. Eur J Endocrinol 1994; 130:125-131.

34 Renner U, Arzberger T, Pagotto U, Leimgruber S, Uhl E, Müller A, Lange M, Weindl A, Stalla GK: Heterogenous dopamine D2 receptor subtype messenger ribonucleic acid expression in clinically nonfunctioning pituitary adenomas. J Clin Endocrinol Metab 1998;83:1368-1375.

35 Renner U, Gloddek J, Arzt E, Inoue K, Stalla GK: Interleukin-6 is an autocrine growth factor for folliculostellate-like TtT/GF mouse pituitary tumor cells. Exp Clin Endocrinol Diabetes 1997; 105:345-352. 
36 Chomczynski P, Sacchi N: Single-step method of RNA isolation by acid guanidinium thiocyanate-phenol-chloroform extraction. Anal Biochem 1987;162:156-159.

37 Turner HE, Nagy Z, Gatter KC, Esiri MM, Harris AL, Wass JA: Angiogenesis in pituitary adenomas and the normal pituitary gland. J Clin Endocrinol Metab 2000;85:1159-1162.

38 Miller GM, Alexander JM, Bikkal HA, Katznelson L, Zervas NT, Klibanski A: Somatostatin receptor subtype gene expression in pituitary adenomas. J Clin Endocrinol Metab 1995;80:1386-1392.

39 Colao A, Ferone D, Marzullo P, Di Sarno A, Certone G, Sarnacchiaro F, Cirillo S, Merola B, Lombardi G: Effect of different dopaminergic agents in the treatment of acromegaly. J Clin Endocrinol Metab 1997;82:518-523.

40 Mercado-Asis LB, Yanovski JA, Tracer HL, Chik CL, Cutler GB: Acute effects of bromocriptine, cyproheptadine, and valproic acid on plasma adrenocorticotropin secretion in Nelson's syndrome. J Clin Endocrinol Metab 1997; 82:514-517.

41 Jaquet P, Ouafik L, Saveanu A, Gunz G, Fina F, Dufour H, Culler MD, Moreau JP, Enjalbert A: Quantitative and functional expression of somatostatin receptor subtypes in human prolactinomas. J Clin Endocrinol Metab 1999;84 3268-3276.
42 Heiss JD, Papavassiliou E, Merill MJ, Nieman L, Knightly JJ, Walbridge S, Edwards NA, Oldfield EH: Mechanism of dexamethasone suppression of brain tumor-associated vascular permeability in rats. J Clin Invest 1996;98: 1400-1408.

43 Nauck M, Roth M, Tamm M, Eickelberg O, Wieland H, Stulz P, Perruchoud AP: Induction of vascular endothelial growth factor by platelet-activating factor and platelet-derived growth factor is downregulated by corticosteroids. Am J Respir Cell Mol Biol 1997;16:398406.

44 Cohen T, Nahari D, Weiss Cerem L, Neufeld G, Levi B-Z: Interleukin-6 induces the expression of vascular endothelial growth factor. $\mathrm{J}$ Biol Chem 1996;271:736-741.

45 Jones TH, Daniels M, James RA, Justice SK, McCorkle R, Price A, Kendall-Taylor P, Weetman AP: Production of bioactive and immunoreactive interleukin-6 (IL-6) and expression of IL-6 messenger ribonucleic acid by human pituitary adenomas. J Clin Endocrinol Metab 1994;78:180-187.

46 Rezai AR, Rezai A, Martinez-Maza O, VanderMayden M, Weiss MH: Interleukin-6 and interleukin-6 receptor gene expression in pituitary tumors. J Neuro-Oncology 1994;19:131135.

47 Ueta Y, Levy A, Chowdrey HS, Lightman SL: S-100 antigen-positive folliculostellate cells are not the source of IL-6 gene expression in human pituitary adenomas. J Neuroendocrinol 1995; 7:467-474.
48 Höfler H, Walter GF, Denk H: Immunhistochemistry of folliculo-stellate cells in normal human adenohypophyses and in pituitary adenomas. Acta Neuropathol 1984;65:35-40.

49 Marin F, Kovacs K, Stefaneanu L, Horvath E, Cheng Z: S-100 protein immunopositivity in human nontumorous hypophyses and pituitary adenomas. Endocr Pathol 1992;3:28-38.

50 Farnoud MR, Kujas M, Derome P, Racadot J, Peillon F, Li JY: Interactions between normal and tumoral tissues at the boundary of human anterior pituitary adenomas. Virchows Arch 1994;424:75-82.

51 Borgundvaag B, Kudlow JE, Mueller SG, George SR: Dopamine receptor activation inhibits estrogen-stimulated transforming growth factor- $\alpha$ gene expression and growth in anterior pituitary, but not in uterus. Endocrinology 1992;130:3453-3458.

52 Finley EL, Ramsdell JS: A transforming growth factor- $\alpha$ pathway is expressed in $\mathrm{GH} 4 \mathrm{C} 1$ rat pituitary tumors and appears necessary for tumor formation. Endocrinology 1994;135:416422.

53 Fukumara D, Xavier R, Sugiura T, Chen Y, Park E, Lu N, Selig M, Nielsen G, Taksir T, Jain RJ, Seed B: Tumour induction of VEGF promoter activity in stromal cells. Cell 1998; 94:715-725.

54 Asa SL, Ezzat S: The cytogenesis and pathogenesis of pituitary adenomas. Endocr Rev 1998; 19:798-827. 